\title{
GMR
}

\section{Genetic parameters and selection of soybean lines based on selection indexes}

\author{
F.G. Teixeira ${ }^{1}$, O.T. Hamawaki ${ }^{1}$, A.P.O. Nogueira ${ }^{1}$, R.L. Hamawaki ${ }^{2}$, \\ G.L. Jorge ${ }^{1}$, C.L. Hamawaki ${ }^{1}$, B.Q.V. Machado ${ }^{1}$ and A.J.O. Santana ${ }^{1}$ \\ ${ }^{1}$ Programa de Melhoramento de Soja, \\ Universidade Federal de Uberlândia, Uberlândia, MG, Brasil \\ ${ }^{2}$ Department of Plant, Soil and Agricultural Systems, \\ Southern Illinois University, Carbondale, IL, USA \\ Corresponding author: F.G. Teixeira \\ E-mail: fernanda.gab.teixeira@gmail.com
}

Genet. Mol. Res. 16 (3): gmr16039750

Received June 12, 2017

Accepted August 11, 2017

Published September 21, 2017

DOI http://dx.doi.org/10.4238/gmr16039750

Copyright (C) 2017 The Authors. This is an open-access article distributed under the terms of the Creative Commons Attribution ShareAlike (CC BY-SA) 4.0 License.

\begin{abstract}
Defining selection criteria is important to obtain promising genotypes in a breeding program. The objective of this study was to estimate genetic parameters for agronomic traits and to perform soybean line selection using selection indices. The experiment was conducted at an experimental area located at Capim Branco farm, belonging to the Federal University of Uberlândia. A total of 37 soybean genotypes were evaluated in randomized complete block design with three replicates, in which twelve agronomic traits were evaluated. Analysis of variance, the Scott-Knott test at the 1 and 5\% level of probability, and selection index analyses were performed. There was genetic variability for all agronomic traits, with medium to high levels of genotype determination coefficient. Twelve lines with a total cycle up to 110 days were observed and grouped with the cultivars MSOY 6101 and UFUS 7910. Three lines, UFUS FG 03, UFUS FG 20, and UFUS FG 31, were highlighted regarding grain yield with higher values than the national average of $3072 \mathrm{~kg} / \mathrm{ha}$. The direct selection
\end{abstract}

Genetics and Molecular Research 16 (3): gmr16039750 
enabled the highest trait individual gains. The Williams (1962) index and the Smith (1936) and Hazel (1943) index presented the highest selection gain for the grain yield character. The genotype-ideotype distance index and the index of the sum of ranks of Mulamba and Mock (1978) presented higher values of total selection gain. The lines UFUS FG 12, UFUS FG 14, UFUS FG 18, UFUS FG 25, and UFUS FG 31 were distinguished as superior genotypes by direct selection methods and selection indexes.

Key words: Glycine max; Direct selection; Selection gains; Simultaneous selection

\section{INTRODUCTION}

Soybean [Glycine $\max$ (L.) Merrill] is considered one of the most important legumes in the world for the production of grains, due to the high protein content and vegetal oil, which is used for human and animal feeding (Lima et al., 2015). Estimates indicate that world soybean production for the 2016/2017 crop can be 336.09 million tons and that Brazil is the world's second largest soybean producer with about 103 million tons of soybeans (CONAB, 2017).

Due to the economic importance of the crop, soybean has been the focus of research, especially in the area of genetic improvement, to obtain improved cultivars, carrying genes capable of expressing broad adaptation and tolerance to biotic and abiotic factors, representing significant contributions to the Productive Sector (Soares et al., 2015).

The selection of superior soybean genotypes is a complex process because the agronomic traits of economic importance are of a quantitative nature, being some correlated with each other and because of their low heritability (Nogueira et al., 2012). Promising genotypes should simultaneously unite some desirable attributes aiming at high yields to meet the demand of the productive sector (Cruz, 2013). Because of the complexity of the most important characters, the use of more efficient selection criteria is required.

Throughout the selection process in breeding programs, the objective is to improve the main character and maintain or improve the expression of other characters simultaneously (Nogueira et al., 2012). However, the direct selection of quantitative inheritance characters, which are influenced by the environment and in many cases are interrelated, can cause a series of unfavorable changes in other characteristics (Vasconcelos et al., 2010).

The selection based on one or a few characters has been shown to be inefficient because it brings about a less favorable performance with the other characters not considered in the selection (Bárbaro et al., 2007). The knowledge of associative behavior among characters of interest allows the identification of variables that can be used in indirect selection for other characters, especially when the heritability of the main character is low (Nogueira et al., 2012; Leite et al., 2016).

One way to improve the efficiency of an improvement program is to select a set of characters of agronomic importance simultaneously. The selection indexes associate the information of several characters and allow making the selection with efficiency, increasing the possibility of success of an improvement program (Vasconcelos et al., 2010; Rosado et al., 2012; Cruz, 2013; Vianna et al., 2013; Leite et al., 2016). Selection is based on the index values obtained by combining all the characters of interest for each unit to be selected and

Genetics and Molecular Research 16 (3): gmr16039750 
evaluating the expected indirect responses from the original characters (Cruz et al., 2012).

Leite et al. (2016), using selection indices to evaluate soybean F8 lines, determined that five genotypes presented agronomic superiority among the 27 in the study. Bárbaro et al. (2007) compared selection strategies in the improvement of soybean F5 populations and found that direct selection brought greater individual gain for one character, differing from the selection indexes that presented higher total gains.

Considering the importance of soybean cultivation and the demand for more productive cultivars, knowledge of the relationship between agronomic traits and the study of indices is essential to obtain a better prediction of gains and greater efficiency in the selection process. In this perspective, the objective of this study was to estimate genetic parameters for agronomic traits and to carry out the selection of soybean lineages using selection indices.

\section{MATERIAL AND METHODS}

The experiment was conducted at the Capim Branco farm in Uberlândia, Minas Gerais, Brazil. A total of 35 soybean lines in the F7 generation, developed by the Soybean Breeding Program of the Federal University of Uberlândia (UFU), and two commercial cultivars MSOY 6101 and UFUS 7910 were evaluated.

The preliminary outline was in randomized blocks with three replicates. Each plot of soybean plants was composed of four rows of $5.0 \mathrm{~m}$ long, spaced $0.50 \mathrm{~m}$ apart, totaling $10 \mathrm{~m}^{2}$. The useful area was formed by the two central lines of each plot, $0.50 \mathrm{~m}$ of each end being eliminated, with a plot area of $4.0 \mathrm{~m}^{2}$.

The experimental area was on dystrophic Dark Red Latosol. Soil preparation was carried out by the conventional planting method, with a plowing and two harrows, the last one being carried out on the eve of the sowing and fertilization of sowing. The fertilization was performed according to the crop requirements, after soil analysis, with NPK 02-28-18 formulation at the dosage of $400 \mathrm{~kg} / \mathrm{ha}$.

Before sowing, the seeds were treated with fungicide Carbendazim and Tiram $\left(\right.$ Protreat ${ }^{\circledR}$ ) and then inoculated with Bradyrhizobium japonicum containing two lines of the bacterium. Manual sowing occurred on March 19, 2016, with approximately 3 to $5 \mathrm{~cm}$ of depth, and density of sixteen plants per linear meter. Weed control was carried out with the application of S-Metolachlor (Dual Gold ${ }^{\circledR}$ ) herbicide after sowing and Haloxifope-P-Methyl (Verdict ${ }^{\mathbb{B}}$ ) 20 days after sowing. After, when necessary, manual weeding kept the crop clean until the end of its cycle.

Thirty days after the emergency, cobalt and molybdenum $\left(\operatorname{Nectar}^{\circledR}\right)$ were applied at 100 $\mathrm{mL} / \mathrm{ha}$. For the control of Phakopsora pachyrhizie (causal agent of Asian rust), applications with Trifoxistrobina and Prothioconazole $\left(\mathrm{Fox}^{\circledR}\right)$ were used in the dosage of $0.4 \mathrm{~L} / \mathrm{ha}$ and, when necessary, pest control was made with Acefato $\left(\right.$ Achero $^{\circledR}$ ) at the dosage of $0.4 \mathrm{~kg} / \mathrm{ha}$ and Thiamethoxam and Lambda-Cyhalothrin (Platinum $\mathrm{Neo}^{\circledR}$ ) with $200 \mathrm{~mL} / \mathrm{ha}$. Continuous irrigations were made to ensure favorable experimental conditions for plant development.

The plants were harvested manually and threshed with the aid of a soybean harvesting machine. In each plot the following evaluations were carried out, according to the stages of development of the culture proposed by Fehr and Caviness (1977): a) Number of days for flowering (NDF): period corresponding to the number of days elapsed between emergence and flowering of $50 \%$ of the useful plot plants with at least one open flower (stage R1); b) Number of days to maturity (NDM): period corresponding to the number of days elapsed from

Genetics and Molecular Research 16 (3): gmr16039750 
emergency to the date when $50 \%$ of the useful area plants present $95 \%$ of mature pods (stage R8); c) Plant height at flowering (PHF): in centimeters (cm), measured from the soil surface to the last node on the main stem, in the R1 stage. This average was determined by the height of five plants sampled randomly in the useful area of each plot; d) Plant height at maturity (PHM): in centimeters $(\mathrm{cm})$, measured from the soil surface to the last node on the main stem of the plant, at stage R8. This average was determined by the height of five plants sampled randomly in the useful area of each plot; e) PHF/PHM ratio: ratio between plant height at flowering and plant height at maturity, determined by the height of five plants sampled randomly in the useful area of each plot; $f$ ) Number of nodes in flowering (NNF): in flowering (stage R1), all visible nodes were counted in the main stem of five plants sampled randomly in the useful area of each plot; g) Number of nodes at maturity (NNM): at maturity (stage R8), all nodes visible on the main stem of five plants randomly sampled were counted in the useful area of each plot; h) Number of productive nodes (NPN): were counted the visible productive nodes on the main stem of five plants sampled randomly in the useful area of each plot; i) Number of branched nodes (NBN): branched nodes were counted visible on the main stem of five plants randomly sampled in the useful area of each plot; $j$ ) Number of pods per plant (NPP): after harvest, all pods of five plants randomly sampled were counted in the useful area of each plot and then averaged per plant; k) Weight of 100 grains (W100G): after the harvest and processing of the plants of the plot useful area, the weight of one hundred grains with eight replications was determined. The weight of each sample was corrected to $13 \%$ humidity.

1) Grain productivity (YIELD): evaluated using harvested and trailed material in each useful plot, transformed to $\mathrm{kg} / \mathrm{ha}$ and corrected to $13 \%$ humidity, according to the equation below:

$$
\mathrm{FW}=\mathrm{IW} \times \frac{100 \mathrm{IH}}{100 \mathrm{FH}}
$$

where FW: corrected final sample weight; IW: initial weight of the sample; IH: initial humidity of the sample; FH: final humidity of the sample (13\%).

To evaluate the existence of genetic variability for the quantitative traits, analyses of variance were performed according to the model below:

$$
Y_{i j}=\mu+G_{i}+B_{j}+\varepsilon_{i j}
$$

where $Y_{\mathrm{ij}}$ : is the value of each character for the $\mathrm{i}$-th genotype in the $\mathrm{j}$-th block; $\mu$ : overall average; $\mathrm{G}_{\mathrm{i}}$ : effect of the $\mathrm{i}$-th genotype; $\mathrm{B}_{\mathrm{i}}$ : effect of the $\mathrm{j}$-th block; ${ }_{\mathrm{ij}}$ : random error. estimator:

The genotypic determination coefficient $\left(\mathrm{H}^{2}\right)$ was estimated according to the following

$$
\mathrm{H}^{2}=\frac{\hat{\varnothing} \mathrm{g}}{\mathrm{QMT} / \mathrm{r}}
$$

Genetics and Molecular Research 16 (3): gmr16039750 


$$
\hat{\theta}_{\mathrm{g}}=\frac{(\mathrm{QMT}-\mathrm{QMR})}{\mathrm{r}}
$$

where $\mathrm{H}^{2}$ : coefficient of genotypic determination; $\hat{\varnothing} \mathrm{g}$ : quadratic genetic component; QMT: average squares of genotypes; QMR: average squares of residue; r: number of repetitions.

The genotypes were clustered based on the Scott-Knott test at the 1 and 5\% probability level.

Then, the estimations of the selection gains were obtained through the selection index methodologies mentioned by Cruz (2006): direct and indirect selection, classic index proposed by Smith (1936) and Hazel (1943), index of the sum of "Ranks" of Mulamba and Mock (1978), base index of Williams (1962), and genotype-ideotype distance index. The selection criterion used was to reduce the NDF and NDM characters, and increase PHF, PHM, NNF, NNM, W100G, NPN, NBN, NPP, and YIELD.

The gain expected by the direct selection (Cruz, 2006) in the $\mathrm{i}$-th character $\left(\mathrm{GS}_{\mathrm{i}}\right)$ was estimated based on the selection differential, using the formula:

$$
\mathrm{GS}_{\mathrm{i}}=\left(\mathrm{X}_{\mathrm{si}}-\mathrm{X}_{\mathrm{oi}}\right) \mathrm{h}_{\mathrm{i}}^{2}=\mathrm{DS}_{\mathrm{i}} \mathrm{h}_{\mathrm{i}}^{2}
$$

where $X_{\mathrm{si}}=$ average of the selected lineages for the character $\mathrm{i} ; \mathrm{X}_{\mathrm{oi}}=$ original population average; $\mathrm{DS}_{\mathrm{i}}=$ selection differential practiced in the population; $\mathrm{h}_{\mathrm{i}}{ }_{\mathrm{i}}=$ heritability of character $\mathrm{i}$.

The indirect gain in character $j$, by selection in character $i$, was given by:

$$
\mathrm{GS}_{\mathrm{j}(\mathrm{i})}=\mathrm{DS}_{\mathrm{j}(\mathrm{i})} \mathrm{h}_{\mathrm{i}}^{2} \quad \text { (Equation 6) }
$$

where $\mathrm{DS}_{\mathrm{j}(\mathrm{i})}$ : a differential of indirect selection obtained as a function of the common character of those individuals whose superiorities were verified based on another character, on which direct selection is practiced.

The classical index proposed by Smith (1936) and Hazel (1943) was estimated by the selection index (I) and the genotypic aggregate $(\mathrm{H})$ described as follows:

$$
\begin{aligned}
& \mathrm{I}=\mathrm{b}_{1} \mathrm{y}_{1}+\mathrm{b}_{2} \mathrm{y}_{2}+\ldots+\mathrm{b}_{\mathrm{n}} \mathrm{y}_{\mathrm{n}}=\sum_{\mathrm{i}=1}^{\mathrm{n}} \mathrm{b}_{\mathrm{i}} \mathrm{y}_{\mathrm{i}}=\mathrm{y}^{\prime} \mathrm{b} \\
& \mathrm{H}=\mathrm{a}_{1} \mathrm{~g}_{1}+\mathrm{a}_{2} \mathrm{~g}_{2}+\ldots+\mathrm{a}_{\mathrm{n}} \mathrm{g}_{\mathrm{n}}=\sum_{\mathrm{i}=1}^{\mathrm{n}} \mathrm{a}_{\mathrm{i}} \mathrm{g}_{\mathrm{i}}=\mathrm{g}^{\prime} \mathrm{a}
\end{aligned}
$$

where $\mathrm{n}$ : number of characters evaluated; $\mathrm{b}$ : vector of dimension $1 \mathrm{x} \mathrm{n}$ of the weighting coefficients of the selection index to be estimated; $\mathrm{y}$ : a matrix of dimension $\mathrm{n} x \mathrm{p}$ (plants) of phenotypic values of the characters; a: is the vector of dimension $1 \times \mathrm{n}$ of economic weights previously established; g: a matrix of dimension $\mathrm{n} x \mathrm{p}$ of unknown genetic values of the $\mathrm{n}$ considered characters.

The vector $\mathrm{b}=\mathrm{P}-1 \mathrm{Ga}$, where $\mathrm{P}-1$ is the inverse of the matrix of dimension $\mathrm{n} \times \mathrm{n}$, of phenotypic variances and covariates between the characters. $G$ is the matrix, of dimension $n$

Genetics and Molecular Research 16 (3): gmr16039750 
$\mathrm{x} n$, of genetic variances and covariances between the characters. The expected gain for the character $\mathrm{j}$ was expressed by:

$$
\Delta g_{j(i)}=\mathrm{DS}_{\mathrm{j}(\mathrm{i})} \mathrm{h}_{\mathrm{j}}^{2}
$$

where $\Delta \mathrm{g}_{\mathrm{j}(\mathrm{I})}=\mathrm{g}_{\mathrm{j}(\mathrm{I})}$ : the expected gain for character $\mathrm{j}$, with selection based on the index I; $\mathrm{DS}_{\mathrm{j}(\mathrm{i})}$ : differential selection for character $\mathrm{j}$, with selection based on the index $\mathrm{I} ; \mathrm{h}_{\mathrm{j}}^{2}$ : heritability of the character $\mathrm{j}$.

In the index of the sum of ranks of Mulamba and Mock (1978) the orders of each genotype were added, resulting in the index of selection, as described below:

$$
\mathrm{I}=\mathrm{r}_{1}+\mathrm{r}_{2}+\ldots+\mathrm{r}_{\mathrm{n}}
$$

(Equation 10)

where I: index value for given individual or family; $\mathrm{r}_{\mathrm{j}}$ : classification (or "rank") of an individual about the $j$-th character; $n$ : number of characters considered in the index.

The weights were given by:

$$
\mathrm{I}=\mathrm{p}_{1} \mathrm{r}_{1}+\mathrm{p}_{2} \mathrm{r}_{2}+\ldots+\mathrm{p}_{\mathrm{n}} \mathrm{r}_{\mathrm{n}}
$$

where $\mathrm{p}_{\mathrm{j}}$ : economic weight attributed to the $\mathrm{j}$-th character. criterion:

For the base index of Williams (1962) the following index was used as selection

$$
\mathrm{I}=\mathrm{a}_{1} \mathrm{y}_{1}+\mathrm{a}_{2} \mathrm{y}_{2}+\ldots+\mathrm{a}_{\mathrm{n}} \mathrm{y}_{\mathrm{n}}=\sum_{\mathrm{i}=1}^{\mathrm{n}} \mathrm{a}_{\mathrm{i}} \mathrm{y}_{\mathrm{i}}=\mathrm{y}^{\prime} \mathrm{a}
$$

where y: are the averages; a: are the economic weights of the characters studied.

In the genotype-ideotype distance index (Cruz, 2006), the average, maximum and minimum values for each variable were calculated. $X_{\mathrm{ij}}$ was considered the average phenotypic value of the $i$-th genotype concerning the $j$-th trait. Also considered was the $Y_{i j}$ value representing the transformed average phenotypic value, and $\mathrm{C}_{\mathrm{j}}$ a constant relative to the depreciation of the common genotype. Thus, we have: $\mathrm{LI}_{j}$ as the lower limit to be presented by the genotype, relative to the characteristic $\mathrm{j}, \mathrm{LS}_{\mathrm{j}}$ as the upper limit to be presented by the genotype and $\mathrm{VO}_{\mathrm{j}}$ as the optimal value to be presented by the genotype, under selection.

If $L I_{j} \leq X_{i j} \leq L S_{j}$, then $Y_{i j}=X_{i j} ;$ If $X_{i j}<L I_{j}, Y_{i j}=X_{i j}+V O_{j}-L I_{j}-C_{j} ;$ If $X_{i j}>L S_{j}, Y_{i j}=$ $\mathrm{X}_{\mathrm{ij}}+\mathrm{VO}_{\mathrm{j}}-\mathrm{LS}_{\mathrm{j}}+\mathrm{C}_{\mathrm{j}}$.

In the procedure, $C_{j}=L_{j}-L_{j}$ was considered. The value $C_{j}$ ensured that any value of $X_{i j}$ within the range around the optimum would result in a value of $Y_{i j}$ with a magnitude close to the optimum value $\left(\mathrm{VO}_{\mathrm{j}}\right)$, unlike the values of $\mathrm{X}_{\mathrm{ij}}$ outside that range. Thus, the $\mathrm{X}_{\mathrm{ij}}$ transformation was performed to ensure the depreciation of phenotypic values out of range. The values of $Y_{i j}$ obtained by transformation were later standardized and weighted by the weights assigned to each characteristic, obtaining the values $y_{i j}$, as specified below:

Genetics and Molecular Research 16 (3): gmr16039750 


$$
y_{i j}=\sqrt{a_{j}} \frac{Y_{i j}}{S\left(Y_{j}\right)}
$$

where $S\left(Y_{j}\right)$ : standard deviation of mean phenotypic values obtained by transformation; $a_{j}$ : weight or economic value of the characteristic.

For calculation, standardization and $\mathrm{VO}_{\mathrm{j}}$ weighting were also required, as specified:

$$
\mathrm{VO}_{\mathrm{ij}}=\sqrt{\mathrm{a}_{\mathrm{j}}} \frac{\mathrm{VO}_{\mathrm{j}}}{\mathrm{S}\left(\mathrm{Y}_{\mathrm{j}}\right)}
$$

where $\mathrm{VO}_{\mathrm{j}}$ : optimum value; $\mathrm{a}_{\mathrm{j}}$ : weight or economic value of the characteristic; $\mathrm{S}\left(\mathrm{Y}_{\mathrm{j}}\right)$ : standard deviation of mean phenotypic values obtained by transformation.

The index values expressed by the distances between the genotype and the ideotype were then calculated, as shown:

$$
I_{\text {DGI }}=\sqrt{\frac{1}{n} \sum_{j=1}^{n}\left(y_{i j}-v_{j}\right)^{2}}
$$

Based on these indices, the best genotypes are identified and the selection gains calculated.

In the direct selection, it was considered a decrease in the number of days for flowering and the number of days for maturity, and an increase for the other characters. For the classic index proposed by Smith (1936) and Hazel (1943), the index of the sum of ranks of Mulamba and Mock (1978), and the base index of Williams (1962), economic weight equal to 1 was adopted for all the characters except productivity, with economic weight equal to 2 . For the genotype-ideotype distance index, the economic weight equal to 1 was adopted for all the characters except productivity, with economic weight equal to 2 . The optimal values, lower and upper limits were determined as desired for culture.

All genetic and statistical analyses were processed through the Computational Program in Genetics and Statistics - GENES Program (Cruz, 2013).

\section{RESULTS AND DISCUSSION}

Genetic variability was observed for all the characters at 1 and $5 \%$ probability by the F-test (Table 1), evidencing the possibility of performing superior lineage selection.

The coefficient of variation (CV) presented values between 2.17 and $77.54 \%$ for NDM and NBN, respectively (Table 1). The CV was higher for NBN (77.54\%), NPP (40.58\%), and YIELD $(23.65 \%)$. The CV above $30 \%$ is considered high, indicating high dispersion of the experimental data, which may have been caused by the genetic and phenotypic differences between the studied materials. High $\mathrm{CV}$ can also be explained by the fact that they are quantitative traits controlled by many genes and highly affected by the environment. It is

Genetics and Molecular Research 16 (3): gmr16039750 
worth mentioning that the CVs obtained in this study are in line with other research on soybean (Espindola et al., 2012; Perini Júnior et al., 2012; Nogueira et al., 2012).

Table 1. Average squares, coefficients of variance, and genetic parameters of agronomic characters and grain yield of 37 soybean genotypes, in the city of Uberlândia - MG.

\begin{tabular}{l|c|c|c|c|c}
\hline Characters & QMG & $\mathrm{H}^{2}(\%)$ & $\mathrm{CVg}(\%)$ & $\mathrm{CVg} / \mathrm{CVe}$ & $\mathrm{CV}(\%)$ \\
\hline NDF & $63.58^{* *}$ & 93.23 & 9.66 & 2.14 & 4.51 \\
\hline NDM & $63.88^{* *}$ & 90.78 & 3.93 & 1.81 & 2.17 \\
\hline PHF & $66.50^{* *}$ & 72.38 & 13.29 & 0.93 & 14.21 \\
\hline PHM & $125.29^{*}$ & 44.55 & 9.75 & 0.51 & 17.85 \\
\hline PHF/PHM & $0.02^{* *}$ & 55.07 & 9.59 & 0.64 & 15.01 \\
\hline NNF & $2.72^{* *}$ & 71.87 & 8.51 & 0.92 & 9.22 \\
\hline NNM & $4.63^{*}$ & 41.04 & 6.96 & 7.48 & 5.46 \\
\hline NPN & $2.55^{* *}$ & 85.45 & 7.87 & 0.76 & 19.87 \\
\hline NBN & $4.48^{* *}$ & 63.51 & 6.13 & 0.80 & 7.54 \\
\hline NPP & $3.07^{* *}$ & 65.68 & 61.94 & 0.48 & 40.58 \\
\hline YIELD & $128.49^{*}$ & 41.15 & 19.59 & 1.29 & 23.65 \\
\hline
\end{tabular}

NDF: number of days for flowering; NDM: number of days to maturity; PHF: plant height at flowering; PHM: plant height at maturity; PHF/PHM: ratio between plant height at flowering and plant height at maturity; NNF: number of nodes in flowering; NNM: number of nodes at maturity; W100G: weight of 100 grains; NPN: number of productive nodes; NBN: number of branched nodes; NPP: number of pods per plant; YIELD: grain productivity; QMG: average square of the genotypes; H2: coefficient of genotypic determination; CV: general coefficient of variation; CVg: coefficient of genetic variation; CVe: coefficient of experimental variation; $* *$ and $*$ significant at the 1 and $5 \%$ probability level, respectively, by the F-test.

The knowledge of the genotypic determination coefficient $\left(\mathrm{H}^{2}\right)$ allows establishing an estimate of the genetic gain to be obtained and defines the best strategy to be used in the breeding program (Baldissera et al., 2014).

Higher estimates of $\mathrm{H}^{2}$ occurred for the number of days for flowering $(93.23 \%)$, number of days for maturity $(90.78 \%)$, weight of one hundred grains $(85.45 \%)$, grain productivity $(83,42 \%)$, plant height at flowering $(72.38 \%)$, and number of nodes at flowering $(71.87 \%)$. These results indicated a strong outlook for phenotypic selection, which can be confirmed with the values obtained in the $\mathrm{CVg} / \mathrm{CVe}$ quotient close to or greater than 1 for these characters. On the other hand, the lowest values of $\mathrm{H}^{2}$ were found for the number of pods $(41.15 \%)$, plant height at maturity (44.55\%), and the number of nodes at maturity (41.04\%) (Table 1).

Evaluating 309 soybean genotypes, Zhang et al. (2015) verified heritability values of $95.6,94.2,92.2$, and $82.8 \%$ for the number of days for flowering, number of days for maturity, number of days to flowering and maturity, and plant height at maturity, respectively.

Bizari et al. (2017) determined that the characters with the highest heritability value were the number of days at maturity $(91.7 \%)$, followed by oil content $(86.21 \%)$, agronomic value $(74.97 \%)$, and grain yield $(71.31 \%)$. The lowest values were found for the number of pods $(54.19 \%)$ and plant height at maturity $(65.73 \%)$, agreeing with the results obtained in this study.

The ratio between the genetic variation coefficient $(\mathrm{CVg})$ and the coefficient of environmental variation $(\mathrm{CVe})$ can be used as indicative of obtaining more significant genetic gains in the selection of superior genotypes (Cruz et al., 2012). When the estimated quotient is greater than or equal to 1, the available genetic variation is the one most responsible for the estimated variation of the experimental data. The $\mathrm{CVg} / \mathrm{CVe}$ ratio can be used as an index indicative of the degree of ease of selection of genotypes for each character (Leite et al., 2016).

Genetics and Molecular Research 16 (3): gmr16039750 
The $\mathrm{CVg} / \mathrm{CV}$ e relations presented values greater than one for the characters NDF, NDM, W100G, and YIELD and values close to one for PHF, PHF/PHM, NNF, NPN, and NBN. This shows that there are satisfactory conditions for selection (Cruz et al., 2012). Also, similar results were found by Unêda-Trevisoli et al. (2010), Leite et al. (2016), and Barros et al. (2016).

The averages of the phenotypic values of the lines and cultivars concerning the characters related to cycle, height, and the number of nodes on the main stem are presented in Table 2. A separation of the genotypes from one to six groups, for NNM and NDF, respectively, was noted.

Table 2. Averages for the number of days for blooming (NDF), number of days to maturity (NDM), plant height at flowering (PHF) in $\mathrm{cm}$, plant height at maturity (PHM) in $\mathrm{cm}$, ratio between the height of the plant at flowering and the height of the plant at maturity (PHF/PHM), number of nodes in flowering (NNF), and number of nodes at maturity of 37 soybean genotypes, in Uberlândia - MG.

\begin{tabular}{|c|c|c|c|c|c|c|c|}
\hline \multirow[t]{2}{*}{ Genotypes } & \multicolumn{7}{|c|}{ Characters } \\
\hline & $\mathrm{NDF}^{* *}$ & $\mathrm{NDM}^{* *}$ & PHF** & PHM* & PHF/PHM** & $\mathrm{NNF}^{* *}$ & NNM $^{*}$ \\
\hline$\overline{\text { UFUS FG } 01}$ & $37.67^{\mathrm{a}}$ & $114.00^{\mathrm{c}}$ & $24.07^{\mathrm{b}}$ & $41.60^{b}$ & $0.60^{\mathrm{b}}$ & $8.87^{\mathrm{b}}$ & $11.93^{\mathrm{a}}$ \\
\hline UFUS FG 02 & $49.00^{\mathrm{d}}$ & $120.00^{\mathrm{d}}$ & $26.27^{b}$ & $31.40^{\mathrm{b}}$ & $0.84^{\mathrm{a}}$ & $9.13^{\mathrm{b}}$ & $10.20^{\mathrm{a}}$ \\
\hline UFUS FG 03 & $33.33^{\mathrm{a}}$ & $113.00^{\mathrm{c}}$ & $22.20^{\mathrm{b}}$ & $35.20^{\mathrm{b}}$ & $0.63^{\mathrm{b}}$ & $9.67^{\mathrm{a}}$ & $11.50^{\mathrm{a}}$ \\
\hline$\overline{\text { UFUS FG } 04}$ & $46.00^{c}$ & $116.00^{\mathrm{c}}$ & $25.30^{\mathrm{b}}$ & $34.20^{\mathrm{b}}$ & $0.76^{\mathrm{a}}$ & $8.40^{\mathrm{b}}$ & $9.80^{\mathrm{a}}$ \\
\hline$\overline{\text { UFUS FG } 05}$ & $44.00^{c}$ & $114.00^{\mathrm{c}}$ & $29.73^{b}$ & $43.13^{\mathrm{b}}$ & $0.69^{\mathrm{b}}$ & $8.80^{\mathrm{b}}$ & $10.67^{\mathrm{a}}$ \\
\hline UFUS FG 06 & $46.00^{c}$ & $114.00^{\circ}$ & $31.00^{\mathrm{b}}$ & $39.80^{\mathrm{b}}$ & $0.78^{\mathrm{a}}$ & $9.80^{\mathrm{a}}$ & $10.70^{\mathrm{a}}$ \\
\hline UFUS FG 07 & $48.33^{\mathrm{d}}$ & $114.00^{\circ}$ & $30.67^{b}$ & $35.87^{b}$ & $0.86^{\mathrm{a}}$ & $8.80^{\mathrm{b}}$ & $10.40^{\mathrm{a}}$ \\
\hline UFUS FG 08 & $41.33^{\mathrm{b}}$ & $108.67^{\mathrm{b}}$ & $30.00^{\mathrm{b}}$ & $45.00^{\mathrm{a}}$ & $0.67^{\mathrm{b}}$ & $9.90^{\mathrm{a}}$ & $10.93^{\mathrm{a}}$ \\
\hline$\overline{\text { UFUS FG } 09}$ & $49.00^{\mathrm{d}}$ & $112.00^{\mathrm{c}}$ & $28.27^{\mathrm{b}}$ & $49.07^{\mathrm{a}}$ & $0.58^{\mathrm{b}}$ & $9.67^{\mathrm{a}}$ & $12.13^{\mathrm{a}}$ \\
\hline UFUS FG 10 & $52.00^{\mathrm{e}}$ & $114.67^{\mathrm{c}}$ & $33.33^{\mathrm{a}}$ & $56.60^{\mathrm{a}}$ & $0.61^{\mathrm{b}}$ & $10.13^{\mathrm{a}}$ & $13.67^{\mathrm{a}}$ \\
\hline UFUS FG 11 & $52.33^{\mathrm{e}}$ & $115.33^{\mathrm{c}}$ & $28.07^{\mathrm{b}}$ & $41.20^{\mathrm{b}}$ & $0.69^{\mathrm{b}}$ & $9.00^{\mathrm{b}}$ & $10.13^{\mathrm{a}}$ \\
\hline UFUS FG 12 & $47.00^{\mathrm{d}}$ & $108.33^{\mathrm{b}}$ & $33.93^{\mathrm{a}}$ & $50.47^{\mathrm{a}}$ & $0.68^{\mathrm{b}}$ & $10.07^{\mathrm{a}}$ & $11.20^{\mathrm{a}}$ \\
\hline$\overline{\text { UFUS FG } 13}$ & $45.00^{c}$ & $101.33^{\mathrm{a}}$ & $35.80^{\mathrm{a}}$ & $45.03^{\mathrm{a}}$ & $0.83^{\mathrm{a}}$ & $8.90^{\mathrm{b}}$ & $10.73^{\mathrm{a}}$ \\
\hline UFUS FG 14 & $43.00^{\mathrm{c}}$ & $109.33^{\mathrm{b}}$ & $29.60^{\mathrm{b}}$ & $51.87^{\mathrm{a}}$ & $0.57^{\mathrm{b}}$ & $10.00^{\mathrm{a}}$ & $11.13^{\mathrm{a}}$ \\
\hline UFUS FG 15 & $47.00^{\mathrm{d}}$ & $107.33^{\mathrm{b}}$ & $29.33^{b}$ & $45.93^{\mathrm{a}}$ & $0.65^{\mathrm{b}}$ & $9.20^{\mathrm{b}}$ & $11.13^{\mathrm{a}}$ \\
\hline UFUS FG 16 & $40.33^{\mathrm{b}}$ & $105.33^{\mathrm{a}}$ & $28.48^{\mathrm{b}}$ & $40.70^{\mathrm{b}}$ & $0.70^{\mathrm{b}}$ & $8.52^{\mathrm{b}}$ & $10.70^{\mathrm{a}}$ \\
\hline UFUS FG 17 & $46.67^{\mathrm{d}}$ & $110.00^{\mathrm{b}}$ & $25.47^{\mathrm{b}}$ & $40.60^{\mathrm{b}}$ & $0.63^{\mathrm{b}}$ & $9.08^{\mathrm{b}}$ & $11.40^{\mathrm{a}}$ \\
\hline UFUS FG 18 & $45.33^{\mathrm{c}}$ & $115.33^{\mathrm{c}}$ & $27.53^{\mathrm{b}}$ & $49.33^{\mathrm{a}}$ & $0.57^{\mathrm{b}}$ & $9.47^{\mathrm{b}}$ & $12.60^{\mathrm{a}}$ \\
\hline UFUS FG 19 & $44.33^{\mathrm{c}}$ & $106.00^{\mathrm{a}}$ & $30.85^{\mathrm{b}}$ & $45.10^{\mathrm{a}}$ & $0.68^{\mathrm{b}}$ & $9.70^{\mathrm{a}}$ & $13.70^{\mathrm{a}}$ \\
\hline$\overline{\text { UFUS FG } 20}$ & $46.00^{c}$ & $114.67^{\circ}$ & $34.67^{\mathrm{a}}$ & $46.80^{\mathrm{a}}$ & $0.75^{\mathrm{a}}$ & $9.33^{\mathrm{b}}$ & $11.47^{\mathrm{a}}$ \\
\hline UFUS FG 21 & $47.67^{\mathrm{d}}$ & $115.33^{\mathrm{c}}$ & $29.10^{\mathrm{b}}$ & $49.80^{\mathrm{a}}$ & $0.65^{\mathrm{b}}$ & $10.63^{\mathrm{a}}$ & $14.20^{\mathrm{a}}$ \\
\hline UFUS FG 22 & $44.00^{c}$ & $112.00^{\mathrm{c}}$ & $28.40^{\mathrm{b}}$ & $45.00^{\mathrm{a}}$ & $0.63^{\mathrm{b}}$ & $8.13^{\mathrm{b}}$ & $11,47^{\mathrm{a}}$ \\
\hline UFUS FG 23 & $45.33^{\mathrm{c}}$ & $111.67^{\mathrm{c}}$ & $34.47^{\mathrm{a}}$ & $41.47^{b}$ & $0.84^{\mathrm{a}}$ & $9.00^{\mathrm{b}}$ & $10.20^{\mathrm{a}}$ \\
\hline UFUS FG 24 & $47.00^{\mathrm{d}}$ & $104.67^{\mathrm{a}}$ & $28.80^{\mathrm{b}}$ & $41.87^{\mathrm{b}}$ & $0.69^{\mathrm{b}}$ & $9.20^{\mathrm{b}}$ & $12.27^{\mathrm{a}}$ \\
\hline UFUS FG 25 & $47.67^{\mathrm{d}}$ & $112.67^{\mathrm{c}}$ & $41.08^{\mathrm{a}}$ & $51.93^{\mathrm{a}}$ & $0.79^{\mathrm{a}}$ & $11.40^{\mathrm{a}}$ & $12.53^{\mathrm{a}}$ \\
\hline UFUS FG 26 & $48.00^{\mathrm{d}}$ & $108.67^{\mathrm{b}}$ & $35.90^{\mathrm{a}}$ & $47.33^{\mathrm{a}}$ & $0.76^{\mathrm{a}}$ & $10.80^{\mathrm{a}}$ & $11.80^{\mathrm{a}}$ \\
\hline UFUS FG 27 & $37.00^{\mathrm{a}}$ & $104.00^{\mathrm{a}}$ & $30.60^{\mathrm{b}}$ & $46.20^{\mathrm{a}}$ & $0.66^{\mathrm{b}}$ & $9.45^{\mathrm{b}}$ & $11.23^{\mathrm{a}}$ \\
\hline UFUS FG 28 & $44.00^{c}$ & $114.00^{\mathrm{c}}$ & $21.00^{\mathrm{b}}$ & $35.00^{\mathrm{b}}$ & $0.62^{\mathrm{b}}$ & $6.97^{\mathrm{b}}$ & $10.13^{\mathrm{a}}$ \\
\hline UFUS FG 29 & $44.00^{c}$ & $113.00^{\mathrm{c}}$ & $23.40^{\mathrm{b}}$ & $35.67^{b}$ & $0.66^{\mathrm{b}}$ & $9.40^{\mathrm{b}}$ & $12.60^{\mathrm{a}}$ \\
\hline UFUS FG 30 & $58.00^{\mathrm{f}}$ & $121.50^{\mathrm{d}}$ & $35.20^{\mathrm{a}}$ & $48.50^{\mathrm{a}}$ & $0.77^{\mathrm{a}}$ & $12.40^{\mathrm{a}}$ & $10.20^{\mathrm{a}}$ \\
\hline UFUS FG 31 & $46.00^{c}$ & $114.00^{\mathrm{c}}$ & $27.40^{\mathrm{b}}$ & $50.00^{\mathrm{a}}$ & $0.59^{\mathrm{b}}$ & $10.50^{\mathrm{a}}$ & $12.70^{\mathrm{a}}$ \\
\hline$\overline{\text { UFUS FG } 32}$ & $55.50^{\mathrm{f}}$ & $117.00^{\circ}$ & $27.90^{\mathrm{b}}$ & $41.40^{\mathrm{b}}$ & $0.71^{\mathrm{b}}$ & $10.00^{\mathrm{a}}$ & $11.70^{\mathrm{a}}$ \\
\hline UFUS FG 33 & $46.00^{\mathrm{c}}$ & $116.00^{\mathrm{c}}$ & $30.10^{\mathrm{b}}$ & $39.70^{\mathrm{b}}$ & $0.77^{\mathrm{a}}$ & $9.10^{\mathrm{b}}$ & $11.10^{\mathrm{a}}$ \\
\hline UFUS FG 34 & $44.00^{\mathrm{d}}$ & $115.00^{\mathrm{c}}$ & $28.60^{\mathrm{b}}$ & $37.40^{\mathrm{b}}$ & $0.77^{\mathrm{a}}$ & $9.10^{\mathrm{b}}$ & $9.80^{\mathrm{a}}$ \\
\hline UFUS FG 35 & $49.50^{\mathrm{d}}$ & $110.50^{\mathrm{b}}$ & $30.20^{\mathrm{b}}$ & $60.03^{\mathrm{a}}$ & $0.51^{\mathrm{b}}$ & $10.20^{\mathrm{a}}$ & $14.40^{\mathrm{a}}$ \\
\hline MSOY 6101 & $48.33^{\mathrm{d}}$ & $110.00^{\mathrm{b}}$ & $42.73^{\mathrm{a}}$ & $52.00^{\mathrm{a}}$ & $0.82^{\mathrm{a}}$ & $10.00^{\mathrm{a}}$ & $11.13^{\mathrm{a}}$ \\
\hline UFUS 7910 & $46.00^{\mathrm{c}}$ & $102.67^{\mathrm{a}}$ & $36.04^{\mathrm{a}}$ & $43.80^{\mathrm{b}}$ & $0.82^{\mathrm{a}}$ & $8.56^{\mathrm{b}}$ & $9.29^{\mathrm{a}}$ \\
\hline
\end{tabular}

Averages followed by similar letters belong to the same group by the Scott-Knott test, ${ }^{* *}$ and $*$ at the 1 and $5 \%$ probability level.

The number of days for flowering ranged from 33 to 58 days. The lineages with the lowest vegetative cycle were UFUS FG 01 (37.67 days), UFUS FG 03 (33.33 days), and UFUS FG 27 (37.00 days), with lower NDF than cultivars MSOY 6101 and UFUS 7910, while the lines with the highest vegetative cycle were UFUS FG 30 (58.00 days) and UFUS FG 32 (55.50 days) (Table 2). 
The number of days of maturity ranged from 101 to 121 days. The earliest lines were UFUS FG 13 (101.33 days), UFUS FG 16 (105.33 days), UFUS FG 19 (106.00 days), UFUS FG 27 (104.00 days), and cultivar UFUS 7910 (102.67 days). Moreover, the later ones were UFUS FG 02 (120.00 days) and UFUS FG 30 (121.50 days) (Table 2).

Twelve genotypes with a complete cycle of up to 110 days were found in the same groups of cultivars MSOY 6101 and UFUS 7910. Cunha et al. (2013) when evaluating soybean cultivars observed that MSOY 6101 presented 109 days for maturity, agreeing with the results obtained in this study, in which the same cultivar reached maturity at 110 days.

Cunha et al. (2013) evaluating 79 soybean progenies in the F5 generation sown in February in Uberlândia - MG, Brazil, found two lineages that stood out with a cycle of 92 days. The authors explain that due to the sowing time, the plants were induced to the early flowering because the soybean is a plant of short days and sensitive to the oscillations of the photoperiod.

In research with soybean lineages in Minas Gerais, Hamawaki et al. (2010) reported a variation in the number of days for flowering from 100 to 128 days, while the number of days to maturity ranged from 164 to 187 days. The results indicated later genotypes than in the present study.

Currently, the use of early-cycle cultivars is desirable in breeding programs, as it allows the use of crop succession system, and the installation of second crop corn after soybean harvest (Cruz et al., 2010; Meotti et al., 2012). Besides, early-cycle genotypes remain less time in the field and are subject to lower effects of biotic and abiotic factors, such as disease pressures and drought impacts (Finoto et al., 2011; Gatut Wahyu et al., 2014).

The height of the flowering plants was 21 to $42 \mathrm{~cm}$, for UFUS FG 28 and MSOY 6101 genotypes, respectively. The height at maturity ranged from 31 to $60 \mathrm{~cm}$ for UFUS FG 02 and UFUS FG 35, respectively (Table 2). The desirable height for mechanical harvesting is about 50 to $60 \mathrm{~cm}$, and plants over $100 \mathrm{~cm}$ in height tend to coat (Cunha et al., 2013).

The lines with a height of 45 to $60 \mathrm{~cm}$ are grouped with the cultivar MSOY 6101. In a study by Cunha et al. (2013), the progenies that stood out for plant height at maturity presented $60 \mathrm{~cm}$ and were in the same group as MSOY 8001. Unêda-Trevisoli et al. (2010) and Selestino et al. (2014) observed values of plant height at maturity greater than $100 \mathrm{~cm}$. The PHF/PHM ratio is an important character in the verification of the type of soybean growth, which can be determined, semi-determined, and indeterminate. The PHF/PHM ratio ranged from 0.51 to 0.86 for UFUS FG 35 and UFUS FG 07 genotypes, respectively (Table 2). Thus, in the type of growth, the majority of the progenies evaluated presented an indeterminate growth. The cultivar MSOY 6101 presented a PHF/PHM ratio of 0.82, but the absence of the terminal, racemose inflorescence, typical of indeterminate growth, was verified.

According to Cunha et al. (2013), genotypes of undetermined growth have been an interesting option for the producer, since cultivars with this type of growth have higher plant height and a greater number of nodes in the main stem. Also, because they have the characteristic of continuous growth, the cultivars tolerate better the adverse conditions, like the humidity, stress or prolonged drought.

The number of nodes in the flowering had an amplitude from 6.97 for the line UFUS FG 28 to 12.40 for the line UFUS FG 30, occurring the formation of two groups (Table 2). Progenies with higher numbers of nodes were grouped with cultivar MSOY 6101 and presented values above 9.67. No groups were formed for the number of nodes at maturity, with a variation of 9.29 and 14.40, for UFUS 7910 and UFUS FG 35 genotypes, respectively.

Genetics and Molecular Research 16 (3): gmr16039750 
Martins et al. (2011) studying 15 cultivars in Santa Maria observed a variation of 16.0 to 20.3 in the number of nodes at maturity, while Perini Júnior et al. (2012) evaluating seven cultivars found values of 12.03 to 16.61 for the same character.

The averages of the phenotypic values of the lines and cultivars concerning the characters of product components, the number of nodes, and productivity are presented in Table 3. The separation of the genotypes from one NPN group into a maximum of three groups for $\mathrm{W} 100 \mathrm{G}$ and YIELD, respectively, was noted.

The W100G is an important factor to reach high productivity, due to the direct correlation between this character and grain yield. Rigon et al. (2012) realized that it is possible to obtain productivity gains when using W100G by indirect selection.

Table 3. Averages of the phenotypic values of the lines and cultivars for the characters 100-grain weight average (W100G), number of productive nodes (NPN), number of branched nodes (NBN), number of pods per plant (NPP), and grain yield (YIELD) in kg/ha, from 37 soybean genotypes, in the city of Uberlândia - MG.

\begin{tabular}{|c|c|c|c|c|c|}
\hline \multirow[t]{2}{*}{ Genotypes } & \multicolumn{5}{|c|}{ Characters } \\
\hline & W100G** & $\mathrm{NPN}^{* *}$ & $\mathrm{NBN}^{* *}$ & NPP* & YIELD** \\
\hline UFUS FG 01 & $11.83^{\mathrm{a}}$ & $6.60^{\mathrm{a}}$ & $1.07^{\mathrm{b}}$ & $17.53^{\mathrm{b}}$ & $2114.80^{\mathrm{c}}$ \\
\hline$\overline{\text { UFUS FG } 02}$ & $9.87^{\mathrm{b}}$ & $6.40^{\mathrm{a}}$ & $0.13^{\mathrm{b}}$ & $11.00^{\mathrm{b}}$ & $812.00^{\mathrm{c}}$ \\
\hline UFUS FG 03 & $10.51^{b}$ & $7.00^{\mathrm{a}}$ & $2.10^{\mathrm{a}}$ & $30.80^{\mathrm{a}}$ & $3708.00^{\mathrm{a}}$ \\
\hline UFUS FG 04 & $10.70^{\mathrm{a}}$ & $5.10^{\mathrm{a}}$ & $1.10^{\mathrm{b}}$ & $14.70^{\mathrm{b}}$ & $1909.50^{\mathrm{c}}$ \\
\hline UFUS FG 05 & $10.43^{b}$ & $6.40^{\mathrm{a}}$ & $0.87^{\mathrm{b}}$ & $23.47^{\mathrm{b}}$ & $3340.20^{\mathrm{b}}$ \\
\hline$\overline{\text { UFUS FG } 06}$ & $10.86^{\mathrm{a}}$ & $5.10^{\mathrm{a}}$ & $3.40^{\mathrm{a}}$ & $29.70^{\mathrm{a}}$ & $2748.30^{\mathrm{b}}$ \\
\hline$\overline{\text { UFUS FG } 07}$ & $11.18^{\mathrm{a}}$ & $5.67^{\mathrm{a}}$ & $0.80^{\mathrm{b}}$ & $12.80^{\mathrm{b}}$ & $1570.80^{\mathrm{c}}$ \\
\hline UFUS FG 08 & $11.79^{\mathrm{a}}$ & $6.40^{\mathrm{a}}$ & $1.00^{\mathrm{b}}$ & $26.80^{\mathrm{a}}$ & $3155.40^{\mathrm{b}}$ \\
\hline UFUS FG 09 & $9.00^{\mathrm{c}}$ & $6.47^{\mathrm{a}}$ & $1.00^{\mathrm{b}}$ & $19.43^{\mathrm{b}}$ & $2174.40^{\mathrm{c}}$ \\
\hline$\overline{\text { UFUS FG } 10}$ & $10.56^{\mathrm{b}}$ & $9.13^{\mathrm{a}}$ & $0.27^{\mathrm{b}}$ & $20.00^{\mathrm{b}}$ & $2624.00^{\mathrm{b}}$ \\
\hline UFUS FG 11 & $12.68^{\mathrm{a}}$ & $5.60^{\mathrm{a}}$ & $0.47^{\mathrm{b}}$ & $11.93^{\mathrm{b}}$ & $1259.40^{\mathrm{c}}$ \\
\hline$\overline{\text { UFUS FG } 12}$ & $11.38^{\mathrm{a}}$ & $6.47^{\mathrm{a}}$ & $0.67^{\mathrm{b}}$ & $19.40^{\mathrm{b}}$ & $3375.60^{\mathrm{b}}$ \\
\hline UFUS FG 13 & $11.65^{\mathrm{a}}$ & $5.93^{\mathrm{a}}$ & $0.87^{\mathrm{b}}$ & $15.40^{\mathrm{b}}$ & $1506.00^{\mathrm{c}}$ \\
\hline UFUS FG 14 & $11.50^{\mathrm{a}}$ & $6.73^{\mathrm{a}}$ & $1.13^{\mathrm{b}}$ & $26.20^{\mathrm{a}}$ & $2911.20^{\mathrm{b}}$ \\
\hline UFUS FG 15 & $9.12^{\mathrm{c}}$ & $5.20^{\mathrm{a}}$ & $1.87^{\mathrm{a}}$ & $16.60^{\mathrm{b}}$ & $2320.80^{\mathrm{c}}$ \\
\hline UFUS FG 16 & $9.58^{\mathrm{c}}$ & $5.87^{\mathrm{a}}$ & $1.12^{\mathrm{b}}$ & $18.88^{\mathrm{b}}$ & $2696.40^{\mathrm{b}}$ \\
\hline UFUS FG 17 & $11.17^{\mathrm{a}}$ & $6.53^{\mathrm{a}}$ & $0.40^{\mathrm{b}}$ & $18.53^{\mathrm{b}}$ & $2468.80^{\mathrm{c}}$ \\
\hline UFUS FG 18 & $12.24^{\mathrm{a}}$ & $7.07^{\mathrm{a}}$ & $0.67^{\mathrm{b}}$ & $23.08^{\mathrm{b}}$ & $2906.80^{\mathrm{b}}$ \\
\hline UFUS FG 19 & $10.28^{b}$ & $7.50^{\mathrm{a}}$ & $2.10^{\mathrm{a}}$ & $26.40^{\mathrm{a}}$ & $2196.00^{\mathrm{c}}$ \\
\hline$\overline{\text { UFUS FG } 20}$ & $10.11^{\mathrm{b}}$ & $6.60^{\mathrm{a}}$ & $1.73^{\mathrm{a}}$ & $27.07^{\mathrm{a}}$ & $4169.40^{\mathrm{a}}$ \\
\hline UFUS FG 21 & $10.50^{\mathrm{b}}$ & $9.07^{\mathrm{a}}$ & $1.47^{\mathrm{b}}$ & $30.73^{\mathrm{a}}$ & $2409.00^{\mathrm{c}}$ \\
\hline UFUS FG 22 & $11.20^{\mathrm{a}}$ & $4.87^{\mathrm{a}}$ & $2.13^{\mathrm{a}}$ & $11.73^{\mathrm{b}}$ & $2091.00^{\mathrm{c}}$ \\
\hline UFUS FG 23 & $9.07^{\mathrm{c}}$ & $4.93^{\mathrm{a}}$ & $1.93^{\mathrm{a}}$ & $20.40^{\mathrm{b}}$ & $1726.00^{\mathrm{c}}$ \\
\hline UFUS FG 24 & $11.93^{\mathrm{a}}$ & $7.93^{\mathrm{a}}$ & $0.65^{\mathrm{b}}$ & $21.47^{b}$ & $2655.20^{\mathrm{b}}$ \\
\hline UFUS FG 25 & $11.16^{\mathrm{a}}$ & $6.73^{\mathrm{a}}$ & $2.47^{\mathrm{a}}$ & $35.60^{\mathrm{a}}$ & $3155.40^{\mathrm{b}}$ \\
\hline UFUS FG 26 & $11.74^{\mathrm{a}}$ & $6.33^{\mathrm{a}}$ & $1.47^{\mathrm{b}}$ & $23.33^{\mathrm{b}}$ & $2281.20^{\mathrm{c}}$ \\
\hline UFUS FG 27 & $10.91^{\mathrm{a}}$ & $5.73^{\mathrm{a}}$ & $0.58^{\mathrm{b}}$ & $18.57^{\mathrm{b}}$ & $2238.67^{\mathrm{c}}$ \\
\hline UFUS FG 28 & $10.76^{\mathrm{a}}$ & $6.60^{\mathrm{a}}$ & $0.13^{\mathrm{b}}$ & $14.27^{b}$ & $1740.60^{\mathrm{c}}$ \\
\hline UFUS FG 29 & $11.15^{\mathrm{a}}$ & $6.33^{\mathrm{a}}$ & $3.13^{\mathrm{a}}$ & $30.93^{\mathrm{a}}$ & $2775.00^{\mathrm{b}}$ \\
\hline UFUS FG 30 & $11.82^{\mathrm{a}}$ & $5.20^{\mathrm{a}}$ & $0.40^{\mathrm{b}}$ & $30.80^{\mathrm{a}}$ & $2063.40^{\mathrm{c}}$ \\
\hline UFUS FG 31 & $11.43^{\mathrm{a}}$ & $7.30^{\mathrm{a}}$ & $2.70^{\mathrm{a}}$ & $33.60^{\mathrm{a}}$ & $4608.00^{\mathrm{a}}$ \\
\hline UFUS FG 32 & $11.14^{\mathrm{a}}$ & $7.40^{\mathrm{a}}$ & $0.00^{\mathrm{b}}$ & $18.70^{\mathrm{b}}$ & $2013.00^{c}$ \\
\hline UFUS FG 33 & $10.81^{\mathrm{a}}$ & $6.70^{\mathrm{a}}$ & $1.50^{\mathrm{b}}$ & $22.10^{\mathrm{b}}$ & $2640.60^{\mathrm{b}}$ \\
\hline UFUS FG 34 & $11.09^{\mathrm{a}}$ & $5.80^{\mathrm{a}}$ & $0.10^{\mathrm{b}}$ & $15.40^{\mathrm{b}}$ & $1655.40^{\mathrm{c}}$ \\
\hline UFUS FG 35 & $10.46^{\mathrm{b}}$ & $10.00^{\mathrm{a}}$ & $1.28^{\mathrm{b}}$ & $19.40^{\mathrm{b}}$ & $2521.50^{\mathrm{b}}$ \\
\hline MSOY6101 & $8.96^{\mathrm{c}}$ & $4.27^{\mathrm{a}}$ & $1.73^{\mathrm{a}}$ & $15.95^{\mathrm{b}}$ & $1714.17^{\mathrm{c}}$ \\
\hline UFUS7910 & $9.85^{\mathrm{b}}$ & $5.07^{\mathrm{a}}$ & $4.57^{\mathrm{a}}$ & $20.07^{\mathrm{b}}$ & $1062.97^{\mathrm{c}}$ \\
\hline
\end{tabular}

Averages followed by similar letters belong to the same group by the Scott-Knott test, $* *$ and $*$ at the 1 and $5 \%$ probability level.

It was found that the W100G was from 8.96 to $12.68 \mathrm{~g}$, for MSOY 6101 and UFUS FG 11, respectively. Three groups were formed, grouping 23 lines among the highest values for this character, being superior to the two subjects (Table 3).

Genetics and Molecular Research 16 (3): gmr16039750 
Evaluating the agronomic performance of soybean cultivars in the central region of the State of Tocantins, Ribeiro et al. (2016) verified two cultivars that presented the highest averages for W100G of 19.88 and $18.58 \mathrm{~g}$. The authors stated that the mass of one hundred grains is a genetically determined attribute but strongly influenced by the environment.

Rigon et al. (2012) with genetic dissimilarity and pathway analysis of soybean cultivars using quantitative descriptors in Rio Grande do Sul, verified a weight of 100 grains ranging from 13.17 to $22.41 \mathrm{~g}$. These results present values superior to those found in the present study.

The variation in the NPN was 4.27 for cultivar MSOY 6101 and 10.00 for the UFUS FG 35 line. The number of branched nodes presented formation of two groups, in which the ten lines with the highest averages were grouped with the subjects, MSOY 6101 and UFUS 7910, with values from 1.73 (UFUS FG 20) to 4.57 (UFUS 7910). The group with the lowest averages had amplitudes of 0.00 to 1.47 for the UFUS FG 32 and UFUS FG 26 lines, respectively (Table 3 ).

Val et al. (2014) evaluated the number of branches and found the formation of two groups, ranging from 1.13 to 5.30 , which corroborates with the present study for the number of branched nodes. Navarro Júnior and Costa (2002) found that for some of the cultivars the number of branches was strongly correlated with grain production; this is because these cultivars have a higher number of fertile nodes in the branches.

The NPP is correlated with soybean productivity, and therefore is one of the most important production components for the culture (Vianna et al., 2013; Leite et al., 2016).

Formation of two groups for the NPP character was observed. The first group consisted of 11 lines that presented higher values than the other genotypes and the MSOY 6101 and UFUS 7910 subjects, with values from 26.20 to 35.60, for UFUS FG 14 and UFUS FG 25, respectively. The other progenies had some pods ranging from 11.00 for the UFUS FG 02 line, to 23.47 for UFUS FG 05 (Table 3).

Val et al. (2014) classified the genotypes into two groups for the number of pods, and seven lines had the highest values between 129.90 and 165.33, higher than those found in the present study. One of the main characteristics to be considered in soybean breeding is grain productivity. There were three lineages that stood out for grain yield: UFUS FG 03 (3708.00 kg/ha), UFUS FG 20 (4169.40 kg/ha), and UFUS FG 31 (4608.00 kg/ha). Among all 37 genotypes, productivity ranged from $812.00 \mathrm{~kg} /$ ha to $4608.00 \mathrm{~kg} / \mathrm{ha}$ (Table 3 ).

Seven lines, UFUS FG 03, UFUS FG 05, UFUS FG 08, UFUS FG 12, UFUS FG 20, UFUS FG 25, and UFUS FG 31, obtained higher yield values than the cultivars MSOY 6101 and UFUS 7910 (Table 3), in which the average national production was $3.072 \mathrm{~kg} / \mathrm{ha}$ in the 2016/2017 harvest (CONAB, 2017). Out-of-season sowing may have influenced productivity reduction for all evaluated genotypes and may have higher values at the recommended time of cultivation.

Similar results were found by Rigon et al. (2012), which obtained productivity value of up to $3780 \mathrm{~kg} / \mathrm{ha}$, and Hamawaki et al. (2010) with a production value of up to $4300.3 \mathrm{~kg} /$ ha. In a study by Ribeiro et al. (2016), all genotypes presented productivity averages above $3000 \mathrm{~kg} / \mathrm{ha}$.

The UFUS FG 31 line was highlighted among all evaluated genotypes (Table 3), with higher values in most of the characters. Its productivity was $4608.00 \mathrm{~kg} / \mathrm{ha}$, higher than the national average of $3.072 \mathrm{~kg} / \mathrm{ha}(\mathrm{CONAB}, 2017)$, in addition to being among the highest values of NPP, NNF, NNM, NPN, NBN, W100G, and PHM.

Genetics and Molecular Research 16 (3): gmr16039750 
The agronomic performance of the lines contributes to the verification of the existing variability for the selection of superior genotypes. However, selecting superior individuals is a complex process, since the characters of agronomic importance are of a quantitative nature (Nogueira et al., 2012; Cruz, 2013; Leite et al., 2016). In this context, it is important to identify the best selection strategy.

Direct selection is directed to only one character of interest and consists of obtaining maximum gains in a single character on which the selection is practiced. Depending on the association of this character with others, favorable or unfavorable responses may occur in characters of secondary importance, which were not considered in the selection process (Cruz, 2013). In the present study, direct selection promoted greater individual gains (Table 4).

The greatest gains obtained with the direct selection were the productivity $(31.02 \%)$, the number of pods $(16.00 \%)$, and the number of productive nodes $(12.42 \%)$. While the direct selection for the number of days for maturity returned the lowest individual gain $(4.58 \%)$ (Table 4), which matches the low CVg (3.93\%) (Table 1).

Table 4. Selection gain estimates (GS\%) obtained for the ten characters evaluated, by direct and indirect selection, for the 35 soybean lines, in Uberlândia - MG.

\begin{tabular}{|c|c|c|c|c|c|c|c|c|c|c|}
\hline \multirow[t]{2}{*}{ Characters } & \multicolumn{10}{|c|}{ GS $\%{ }^{1}$} \\
\hline & NDF & NDM & PHF & PHM & NNF & NNM & P100G & NPN & YIELD & NPP \\
\hline NDF & -10.27 & -3.91 & 4.08 & 5.27 & 7.13 & 2.69 & 0.90 & 0.90 & -4.38 & -1.00 \\
\hline NDM & -1.09 & -4.58 & -0.60 & 1.02 & 0.88 & -0.22 & -0.65 & -0.09 & 0.16 & 0.95 \\
\hline PHF & -6.17 & 3.67 & 10.75 & 4.18 & 5.90 & 0.81 & 1.32 & -2.00 & 0.72 & 1.87 \\
\hline PHM & -2.00 & 1.88 & 3.19 & 7.49 & 6.56 & 4.77 & 2.09 & 3.97 & 1.87 & 0.75 \\
\hline NNF & -4.03 & 0.51 & 4.87 & 7.07 & 8.33 & 3.94 & 2.99 & 3.34 & 2.61 & 5.77 \\
\hline NNM & -1.14 & -0.07 & 0.51 & 4.13 & 3.61 & 6.68 & -0.24 & 5.44 & 0.99 & 2.34 \\
\hline P100G & 0.48 & 0.64 & -0.31 & 0.77 & 2.03 & -0.25 & 7.29 & 1.16 & 2.03 & 0.44 \\
\hline NPN & -2.53 & -1.12 & -1.27 & 7.95 & 8.13 & 10.98 & -0.22 & 12.42 & 1.52 & 1.70 \\
\hline PROD & 6.76 & 2.02 & 3.70 & 13.31 & 10.70 & 10.91 & 2.43 & 12.66 & 31.02 & 20.71 \\
\hline NPP & 0.55 & -0.59 & 5.92 & 7.80 & 7.71 & 8.25 & 2.59 & 6.34 & 11.27 & 16.00 \\
\hline Total & -19.44 & -1.55 & 30.84 & 58.99 & 60.98 & 48.56 & 18.5 & 44.14 & 49.53 & 47.81 \\
\hline
\end{tabular}

NDF: number of days for flowering, NDM: number of days to maturity, PHF: height of the plant in flowering, PHM: plant height at maturity, NNF: number of nodes in flowering, NNM: number of nodes at maturity, W100G: weight of 100 grains, NPN: number of productive nodes, YIELD: grain productivity, and NPP: number of pods per plant. ${ }^{1}$ Favorable selection sense: reduction for NDF and NDM, increase for PHF, PHM, NNF, NNM, W100G, NPN, YIELD, and NVT.

Bizari et al. (2017) found similar gains for direct selection in soybean, with higher productivity gains $(35.70 \%)$. This gain occurs due to the greater genetic variation of this character. Besides, they found lower selection gain for the number of days to maturity (3.29\%).

The direct selection for PHM, NNF, NNM, NPN, and NPP brought indirect selection gains for productivity higher than the selected characters, with values of 13.31, 10.70, 10.91, 12.66 , and $20.71 \%$, respectively (Table 4), with highlight to direct selection for the number of pods that brought the highest indirect gain for productivity.

Alcântara Neto et al. (2011) concluded that the number of pods per plant was the production component that had the greatest direct effect on grain production, which corroborates the results found in the present study.

Leite et al. (2016), based on the results observed in the direct selection for plant height traits at flowering and maturity, found a favorable effect with a high contribution in the determination of grain productivity by the number of pods and the number of nodes, respectively.

Genetics and Molecular Research 16 (3): gmr16039750 
The direct selection for the number of days to flowering and maturity, plant height to flowering, and weight of one hundred grains resulted in unfavorable responses to secondary characters, with low values for indirect selection gains (Table 4).

Different from the direct selection, the selection indexes are an alternative that allows making the simultaneous selection with efficiency, by the combination of several characters (Rosado et al., 2012; Cruz, 2013). The selection gains obtained by the classic index proposed by Smith (1936) and Hazel (1943), the index of the sum of ranks of Mulamba and Mock (1978), base index of Williams (1962), and genotype-ideotype distance index are shown in Table 5.

Table 5. Estimates of selection gains (GS\%) obtained for 10 characters by selection by the classic index proposed by Smith (1936) and Hazel (1943), index of the sum of "ranks" of Mulamba and Mock (1978), base index of Williams (1962), and genotype-ideotype distance index for the 35 soybean lines, in Uberlândia - MG.

\begin{tabular}{l|c|c|c|c}
\hline \multirow{2}{*}{ Characters } & \multicolumn{4}{|c}{ GS\% ${ }^{1}$} \\
\cline { 2 - 5 } & Smith (1936) and Hazel (1943) & Mulamba and Mock (1978) & Williams (1962) & Genotype-ideotype distance \\
\hline NDF & -5.13 & -0.01 & -4.38 & 2.83 \\
\hline NDM & -0.45 & -1.82 & 0.16 & -0.6 \\
\hline PHF & 1.81 & 4.10 & 0.72 & 4.44 \\
\hline PHM & 2.35 & 5.11 & 1.87 & 6.68 \\
\hline NNF & 1.95 & 4.64 & 2.61 & 5.52 \\
\hline NNM & 0.19 & 3.49 & 0.99 & 2.03 \\
\hline P100G & 0.83 & 3.71 & 1.52 & 10.95 \\
\hline NPN & 1.10 & 6.42 & 31.02 & 15.62 \\
\hline YIELD & 30.76 & 16.67 & 11.27 & 6.79 \\
\hline NPP & 9.03 & 7.25 & 47.81 & 59.38 \\
\hline Total & 42.44 & 49.56 & & \\
\hline
\end{tabular}

NDF: number of days for flowering, NDM: number of days to maturity, PHF: height of the plant in flowering, PHM: plant height at maturity, NNF: number of nodes in flowering, NNM: number of nodes at maturity, W100G: weight of 100 grains, NPN: number of productive nodes, YIELD: grain productivity and NPP: number of pods per plant. ${ }^{1}$ Favorable negative selection for NDF and NDM and positive for PHF, PHM, NNF, NNM, W100G, NPN, YIELD, and NPP.

In general, the base index of Williams (1962) presented the highest productivity gain $(31.02 \%)$ (Table 5), with a value equal to that found through direct selection (Table 4), followed by Smith's index (1936) and Hazel (1943), with a productivity gain of 30.76\%. However, these two indices had the lowest values of selection gains for the other characters (Table 5).

Heffner et al. (2011) state that the base index of Williams (1962) is theoretically lower than the Smith-Hazel index, but may be favorable when large datasets are not available for accurate estimation of phenotypic correlations.

Studying soybean lines in the F8 generation in Piauí, Leite et al. (2016) observed that the classic Smith and Hazel index and the Williams' base index had the highest genetic gains for soybean grain productivity, with 16.71 and $21.84 \%$, respectively. The results are similar to the present study but had lower selection gain values.

The genotype-ideotype distance index presented the highest total gain value of $59.38 \%$, followed by the sum of ranks of Mulamba and Mock (1978), with 49.56\%. These indexes presented lower values of selection gain for productivity, but higher values for the other characters, providing a balanced distribution of selection gains.

In the study by Leite et al. (2016), the index based on the sum of ranks provided higher values of total gains in soybean, with $36.9 \%$ when considering grain productivity, node

Genetics and Molecular Research 16 (3): gmr16039750 
numbers, and the number of pods as main characters, and $58.52 \%$ when all characters are considered as the main characters. However, the Williams base index was treated in this study as the most appropriate criterion for the analyzed situation.

Bizari et al. (2017), when comparing different selection indices in soybean segregating populations, found that the rank-based index provided the most favorable gains in the study. It was also used the direct selection criteria, Smith and Hazel classic index, the Williams' base index, the index based on the desired gains of Pesek and Baker, and distance index genotype-ideotype.

Vasconcelos et al. (2010), when evaluating different selection criteria in alfalfa genotypes, verified that the Mulamba and Mock indices and distance from the genotype to the ideotype provided superior genetic progress in alfalfa compared to Smith and Hazel and Williams indexes. Despite obtaining the highest gains for a given character, direct selection caused undesirable effects in other characteristics.

Rosado et al. (2012), on the other hand, verified that the ranking index of Mulamba and Mock ranks was more adequate, providing a balanced distribution of selection gains for a greater number of yellow passion fruit progenies evaluated in Minas Gerais.

Table 6 shows the top 10 progenies, selected using all the selection methods used in the present study, their production values and the MSOY 6101 and UFUS 7910 subjects. Direct selection for productivity selected the same genotypes as the classic Williams index.

All genotypes selected are superior to cultivars MSOY 6101 and UFUS 7910 for productivity (Table 6) and other characters (Tables 2 and 3). The lines UFUS FG 12, UFUS FG 14, UFUS FG 18, UFUS FG 25, and UFUS FG 31 were selected in all the selection methods applied in this study, verifying the real superiority of these genotypes.

Table 6. Productivity (YIELD) in $\mathrm{kg} / \mathrm{ha}$ of the ten superior genotypes selected by direct selection for productivity, the classic index proposed by Smith (1936) and Hazel (1943), the index of the sum of ranks of Mulamba and Mock (1978), the base index of Williams (1962), the genotype-ideotype distance index, and subjects MSOY6101 and UFUS7910, in the city of Uberlândia - MG.

\begin{tabular}{|c|c|c|c|c|c|c|c|}
\hline \multicolumn{8}{|c|}{ Selection indices } \\
\hline \multicolumn{2}{|c|}{ Williams (1962) and selection direct productivity } & \multicolumn{2}{|c|}{ Smith (1936) and Hazel (1943) } & \multicolumn{2}{|c|}{ Mulamba and Mock (1978) } & \multicolumn{2}{|c|}{ Genotype-ideotype distance } \\
\hline Genotypes & Yield & Genotypes & Yield & Genotypes & Yield & Genotypes & Yield \\
\hline 3 & 3708.00 & 3 & 3708.00 & 8 & 3155.40 & 10 & 2624.00 \\
\hline 5 & 3340.20 & 5 & 3340.20 & 12 & 3375.60 & 12 & 3375.60 \\
\hline 8 & 3155.40 & 8 & 3155.40 & 14 & 2911.20 & 14 & 2911.20 \\
\hline$\overline{12}$ & 3375.60 & 12 & 3375.60 & 18 & 2906.80 & 18 & 2906.80 \\
\hline 14 & 2911.20 & 14 & 2911.20 & 19 & 2196.00 & 21 & 2409.00 \\
\hline 18 & 2906.80 & 16 & 2696.40 & 24 & 2655.20 & 24 & 2655.20 \\
\hline 20 & 4169.40 & 18 & 2906.80 & 25 & 3155.40 & 25 & 3155.40 \\
\hline 25 & 3155.40 & 20 & 4169.40 & 26 & 2281.20 & 26 & 2281.20 \\
\hline 29 & 2775.00 & 25 & 3155.40 & 31 & 4608.00 & 31 & 4608.00 \\
\hline 31 & 4608.00 & 31 & 4608.00 & 35 & 2521.50 & 35 & 2521.50 \\
\hline \multicolumn{2}{|c|}{ MSOY 6101} & \multicolumn{6}{|c|}{1714.17} \\
\hline \multicolumn{2}{|c|}{ UFUS 7910} & \multicolumn{6}{|c|}{1062.97} \\
\hline
\end{tabular}

In conclusion, the present study found a medium to high genotypic determination coefficient $\left(\mathrm{H}^{2}\right)$ for the characteristics related to cycle, plant height, number of nodes, production components, and productivity. The base index of Williams (1962) and the classic index proposed by Smith (1936) and Hazel (1943) presented the highest selection gain for the grain productivity character. The genotype-ideotype distance index and the index of the sum of ranks of Mulamba and Mock (1978) presented higher values of total selection gain. The lineages UFUS FG 12, UFUS FG 14, UFUS FG 18, UFUS FG 25 and UFUS FG 31 were distinguished as superior genotypes by direct selection methods and selection indexes.

Genetics and Molecular Research 16 (3): gmr16039750 


\section{ACKNOWLEDGMENTS}

The authors thank FAPEMIG, CNPq, and CAPES for financial support and all of the Soybean Breeding Program of the Federal University of Uberlândia that contributed to the study.

\section{REFERENCES}

Alcântara Neto F, Gravina GA, Monteiro MMS, Morais FB, et al. (2011). Análise de trilha do rendimento de grãos de soja na microrregião do Alto Médio Gurguéia. Comun. Sci. 2: 107-112.

Baldissera JNC, Valentini G, Coan MMD, Guidolin AF, et al. (2014). Genetics factors related with the inheritance in autogamous plant populations. Rev. Ciênc. Agrovet. 13: 181-189.

Bárbaro IM, Da Cruz Centurion MAP, Di Mauro AO, Unêda-Trevisoli SH, et al. (2007). Comparação de estratégias de seleção no melhoramento de populações F5 de soja. Rev. Ceres 54: 250-261.

Barros JPA, Sediyama T, Santos Silva FC, Da Silva AF, et al. (2016). Estimates of genetic parameters and efficiency in selection for branching capacity in soybean genotypes. J. Agron. 15: 39-44. https://doi.org/10.3923/ja.2016.39.44

Bizari EH, Val BHP, Pereira EDM, Mauro AOD, et al. (2017). Selection indices for agronomic traits in segregating populations of soybean. Rev. Cienc. Agron. 48: 110-117.

CONAB (Companhia Nacional de Abastecimento) (2017). Acompanhamento da safra brasileira: grãos - safra 2016/17 quarto levantamento. Monthly Report, CONAB, Brazil.

Cruz CD (2006). Programa GENES: biometria. 1st edn. UFV, Viçosa.

Cruz CD (2013). Genes: a software package for analysis in experimental statistics and quantitative genetics. Acta Sci. Agron. 35: 271-276. https://doi.org/10.4025/actasciagron.v35i3.21251

Cruz CD, Regazzi AJ and Carneiro PCS (2012). Modelos biométricos aplicados ao melhoramento genético. 4th edn. UFV, Viçosa.

Cruz TV, Peixoto CP and Martins MC (2010). Crescimento e produtividade de soja em diferentes épocas de semeadura no oeste da Bahia. Sci. Agr. 11: 33-42.

Cunha MCG, Hamawaki OT and Sousa LB (2013). Genetic variability among 79 soybean progenies from UFU-Breeding Program. Biosci. J. 29.

Espindola S, Finholdt R, Ferreira JA, Jr., Kitano B, et al. (2012). Avaliação da performance produtiva e agronômica de genótipos de soja para a região de Jaboticabal, SP. FAZU Rev 8: 20-24.

Fehr WR and Caviness CE (1977). Stages of soybean development. Special report 80. Iowa State University of Science and Technology, Ames.

Finoto EL, Carrega WC, Sediyama T, De Albuquerque JAA, et al. (2011). Efeito da aplicação de fungicida sobre caracteres agronômicos e severidade das doenças de final de ciclo na cultura da soja.Rev.Agro@mbiente. Online (Bergh.) 5: 44-49.

Gatut Wahyu AS, Mangoendidjojo W, Yudono P and Kasno A (2014). Mode of inheritance of genes control maturity in soybean. ARPN J. Agric. Biol. Sci. 9: 178-182.

Hamawaki OT, De Sousa LB, Rezende DF and Hamawaki CDL (2010). Yield and agronomic characteristics of soybean breeding lines in Minas Gerais State, Brazil. Comun. Sci. 1: 43-47.

Hazel LN (1943). The genetic basis for constructing selection indexes. Genetics 28: 476-490.

Heffner EL, Jannink JL and Sorrells ME (2011). Genomic selection accuracy using multifamily prediction models in a wheat breeding program. Plant Genome 4: 65-75. https://doi.org/10.3835/plantgenome.2010.12.0029

Leite WS, Pavan BE, Matos Filho CHA, De Alcantara Neto F, et al. (2016). Genetic parameters estimation, correlations and selection indexes for six agronomic traits in soybean lines F8. Comun. Sci. 7: 302-310. https://doi.org/10.14295/ cs.v7i3.1176

Lima IP, Bruzi AT, Botelho FBS, Zambiazzi EV, et al. (2015). Performance of Conventional and Transgenic Soybean Cultivars in the South and Alto Paranaiba Regions of Minas Gerais, Brazil. Am. J. Plant Sci. 6: 1385. https://doi. org/10.4236/ajps.2015.69138

Martins JD, Streck NA and Carlesso AEKR (2011). Plastocrono e número final de nós de cultivares de soja em função da época de semeadura. Cienc. Rural 41: 954-959. https://doi.org/10.1590/S0103-84782011005000064

Meotti GV, Benin G, Silva RR and Beche E (2012). Épocas de semeadura e desempenho agronômico de cultivares de soja. Pesqui. Agropecu. Bras. 47: 14-21. https://doi.org/10.1590/S0100-204X2012000100003

Mulamba NN and Mock JJ (1978). Improvement of yield potential of the Eto Blanco maize (Zea mays L.) population by breeding for plant traits. Egypt. J. Genet. Cytol. 7: 40-51.

Genetics and Molecular Research 16 (3): gmr16039750 
Navarro Júnior H and Costa JA (2002). Contribuição relativa dos componentes do rendimento para produção de grãos em soja. Pesqui. Agropecu. Bras. 37: 269-274. https://doi.org/10.1590/S0100-204X2002000300006

Nogueira APO, Sediyama T, Sousa LB, Hamawaki OT, et al. (2012). Análise de trilha e correlações entre caracteres em soja cultivada em duas épocas de semeadura. Biosci. J. 28: 877-888.

Perini Júnior LJ, Fonseca Júnior NDS, Destro D and Prete CEC (2012). Components of the production in soybean cultivars with determinate and indeterminate growth. Semin. Cienc. Agrar. 33: 2531-2544.

Ribeiro FC, Colombo GA, Silva POS, Da Silva JIC, et al. (2016). Desempenho agronômico de cultivares de soja na região central do Estado do Tocantins, safra 2014/2015. Sci. Plena 12: No. 7.

Rigon JPG, Capuani S, De Brito Neto JF and Da Rosa GM (2012). Dissimilaridade genética e análise de trilha de cultivares de soja avaliada por meio de descritores quantitativos. Rev. Ceres 59: 233-240. https://doi.org/10.1590/ $\underline{\text { S0034-737X2012000200012 }}$

Rosado LDS, Santos CEMD, Bruckner CH, Nunes ES, et al. (2012). Simultaneous selection in progenies of yellow passion fruit using selection indices. Rev. Ceres 59: 95-101. https://doi.org/10.1590/S0034-737X2012000100014

Selestino PR, Unêda-Trevisoli SH, Silva FM, Pereira EM, et al. (2014). Performance agronômica de genótipos precoces de soja destinados a áreas de reforma de canavial. Ciênc. Tecnol. 6: 59-71.

Smith HF (1936). A discriminant function for plant selection. Ann. Eugen. 7: 240-250. https://doi. org/10.1111/j.1469-1809.1936.tb02143.x

Soares IO, Rezende PM, Bruzi AT, Zambiazzi EV, et al. (2015). Adaptability of soybean cultivars in different crop years. Genet. Mol. Res. 14: 8995-9003. https://doi.org/10.4238/2015.August.7.8

Unêda-Trevisoli SH, Cardoso GKR, Di Mauro AO, Blat SF, et al. (2010). Avaliação de cultivares de soja precoces para cultivo em áreas de reforma de cana-de-açúcar. Ciênc. Tecnol. 1: 50-57.

Val BHP, Júnior JAF, Bizari EH, Di Mauro AO, et al. (2014). Diversidade genética de genótipos de soja por meio de caracteres agromorfológicos. Ciênc. Tecnol. 6: 72-83.

Vasconcelos ES, Ferreira RP, Cruz CD, Moreira A, et al. (2010). Estimativas de ganho genético por diferentes critérios de seleção em genótipos de alfafa. Rev. Ceres 57: 205-210. https://doi.org/10.1590/S0034-737X2010000200011

Vianna VF, Desideriosup JA, De Santiagosup S, Juniorsup JAF, et al. (2013). The multivariate approach and influence of characters in selecting superior soybean genotypes. Afr. J. Agric. Res. 8: 4162-4169.

Williams JS (1962). The evaluation of a selection index. Biometrics 18: 375-393. https://doi.org/10.2307/2527479

Zhang J, Song Q, Cregan PB, Nelson RL, et al. (2015). Genome-wide association study for flowering time, maturity dates and plant height in early maturing soybean (Glycine max) germplasm. BMC Genomics 16: 217. https://doi. org/10.1186/s12864-015-1441-4

Genetics and Molecular Research 16 (3): gmr16039750 